\title{
DESAIN PEMBELAJARAN: Potret Profesionalitas Dosen
}

\author{
Oleh: Askar Ahmad
}

\begin{abstract}
The professional lecturer has to own some competences such as pedagogical, personal, professional, and social competence. Pedagogical competence is the ability to manage the students to learn. To manage the learning well, it must be begun with activity in order to plan and design the learning. The design of learning consist of the formulation of the objective of learning which will be achieved, the development of the learning material or subject matter, it should be suitable with the objective of learning will be achieved, formulate the strategy and the learning method, and also design of the learning media which supports the achievement toward the objective of the learning, as well as evaluate so that to measure the lesson achievement whether the process or its result. The ability to design the learning is one of decision factors which support the level of lecturer's profession.
\end{abstract}

KEYWORDS: Desain pembelajaran, profesionalitas, sertifikasi

LEMBAGA pendidikan pada umumnya dan pendidikan Islam khususnya selalu berfungsi ganda. Di satu sisi lembaga pendidikan berfungsi sebagai pusat pengembangan sains dan teknologi, tetapi di sisi lain lembaga pendidikan juga memiliki fungsi sebagai pusat pengembangan peradaban dan pusat pembudidayaan manusia. Dalam pendidikan Islam, pengembangan sains dan teknologi mengarah pada pengembangan sains dan teknologi yang berwawasan islami, yang pada gilirannya dapat membangun peradaban dan mengembangkan sumber daya manusia yang memiliki wawasan dan kesadaran keagamaan (Islam).

Untuk menunjang fungsi pendidikan Islam tersebut, maka perlu diperhatikan segala sesuatu yang mendukung keberhasilan program pendidikan. Salah satu faktor dominan yang sangat menentukan keberhasilan pendidikan adalah kesuksesan dalam proses pembelajaran, sebab di dalam proses pembelajaran itulah terjadinya proses internalisasi nilai-nilai dan pewarisan budaya maupun norma-norma secara langsung.

Dalam beberapa tahun terakhir ini terjadi pergeseran paradigma yang sangat mendasar dalam proses pembelajaran. Salah satu contohnya 
adalah bergesernya paradigma dari "apa yang mesti diajarkan oleh dosen kepada mahasiswa besok" ke "apa yang harus mahasiswa pelajari dari dosen besok". Paradigma yang disebut pertama menggambarkan bahwa yang aktif dalam proses pembelajaran adalah dosen itu sendiri, sedangkan paradigma kedua menggambarkan bahwa mahasiswalah yang harus berperan aktif dalam proses pembelajaran. Paradigma pertama berangkat dari landasan behavioristik sedangkan paradigma kedua berangkat dari landasan konstruktivistik.

Paradigma di atas mengandung makna lebih dalam bahwa tingkat keberhasilan mengajar bukan pada seberapa banyak ilmu yang disampaikan oleh dosen kepada mahasiswa, tetapi seberapa besar dosen memberi peluang kepada mahasiswa untuk belajar dan memperoleh segala sesuatu yang ingin diketahuinya. ${ }^{1}$ Paradigma ini juga kemudian menyebabkan berubahnya pengertian mengajar. Mengajar dalam paradigma ini adalah suatu kegiatan yang dilakukan oleh seseorang untuk membantu orang lain mencapai kemajuan dalam berbagai aspek seoptimal mungkin sesuai dengan kompetensinya. ${ }^{2}$

Diakui atau tidak masih banyak dosen yang masuk ke dalam kelas untuk mengajar tanpa melakukan perencanaan dan persiapan pembelajaran terlebih dahulu. Mereka berangkat dari sebuah alasan bahwa materi yang akan disampaikan sudah dikuasainya karena telah diajarkan sejak bertahun-tahun dan materi itu telah dihafal di luar kepala. Alasan ini di satu sisi boleh jadi benar, tetapi yang harus disadari bahwa kesukesan dalam proses pembelejaran tidak hanya tergantung pada penguasaan materi tetapi juga harus menyadari tujuan apa yang ingin dicapai dalam pembelajaran, bagaimana cara mencapainya, serta alat ukur apa yang digunakan untuk mengetahui ketercapaian tersebut.

Dari sinilah kemudian sangat terasa arti penting untuk mendesain pembelajaran sebagai kunci sukses dalam proses pembelajaran. Kemampuan untuk mendesain pembelajaran juga dapat dijadikan sebagai salah satu patron untuk memotret tingkat profesaionalitas dosen.

\section{DESAIN PEMBELAJARAN}

Desain pembelajaran adalah sebuah konstruksi secara utuh tentang proses pembelajaran yang akan dilakukan seorang dosen di dalam kelas. Desain pembelajaran meliputi tujuan pembelajaran (learning objectives) yang akan dicapai, pengembangan materi perkuliahan atau desain mata kuliah, strategi pembelajaran (instruction strategies) yang digunakan, serta penilaian hasil belajar (evaluation). ${ }^{3}$ Tujuan pembelajaran sangat terkait erat dengan standar kompetensi dan kompetensi dasar yang ingin dicapai. 
Standar kompetensi berkaitan dengan tujuan yang ingin dicapai setelah suatu mata kuliah itu selesai diajarkan, sedangkan kompetensi dasar berkaitan dengan tujuan yang ingin dicapai setelah suatu pokok bahasan dari materi pelajaran selesai diajarkan, standar kompetensi bersifat umum sedangkan kompetensi dasar bersifat khusus. Strategi pembelajaran berkaitan dengan strategi atau cara-cara yang ditempuh oleh dosen dalam proses belajar-mengajar sehingga tujuan pembelajaran dapat dicapai. Evaluasi pembelajaran dilakukan untuk mengukur apakah tujuan pembelajaran yang telah ditetapkan telah dicapai setelah melalui proses pembelajaran.

Dalam desain pembelajaran dikenal berbagai model yang dikemukakan oleh para ahli, antara lain yang dikembangkan oleh Dick and Carey serta model yang dikembangkan Kemp et. al. Komponen dasar dari kedua model desain pembelajaran tersebut adalah:

1. Menganalisis pebelajar (pihak yang menjadi fokus) yang perlu diketahui karakterstiknya, kemampuan awal dan prasyarat.

2. Tujuan pembelajaran (umum dan khusus) adalah penjabaran kompetensi yang akan dikuasai oleh pebelajar/mahasiswa

3. Analisis pembelajaran merupakan proses menganalisis topik atau materi yang akan dipelajari oleh pebelajar/mahasiswa

4. Strategi pembelajaran dapat dilakukan dalam kurun satu tahun persemesteran atau dalam setiap kegiatan belajar mengajar

5. Bahan ajar adalah format materi yang akan diberikan kepada pebelajar/ mahasiswa

6. Penilaian belajar adalah suatu proses untuk mengukur kemampuan atau kompetensi yang telah dicapai/dikuasai oleh mahasiswa setelah melalui proses pembelajaran. ${ }^{4}$

Model lain dalam desain pembelajaran yang merupakan formulasi dari berbagai bentuk kegiatan belajar-mengajar yaitu model ASSURE, komponen dasarnya adalah:

1. Analyzer learner (menganalisa pebelajar/mahasiswa)

2. State objective (merumuskan tujuan pembelajaran dan kompetensi)

3. Select method, media, and materials (memilih metode, media, dan bahan ajar)

4. Utilize media and materials (menggunakan media dan bahan ajar)

5. Require learner participation (mengembangkan peran serta mahasiswa)

6. Evaluate and Revise (menilai dan memperbaiki). ${ }^{5}$

Desain pembelajaran adalah suatu proses yang dilakukan oleh seorang dosen untuk menganalisis berbagai aspek pembelajaran seperti kebutuhan belajar dan tujuan pembelajaran serta pengembangan teknik 
mengajar dan pengembangan materi pengajaran/perkuliahan untuk memenuhi kebutuhan pendidikan yang terus berkembang. ${ }^{6}$ Kegiatan mendesain pembelajaran adalah suatu proses untuk melakukan alur kerja pembelajaran yang sistematis dengan menganalisis kebutuhan belajar mahasiswa, mengenalisis cara memenuhi kebutuhan belajar dan bagaimana membelajarkan mahasiswa baik dari segi strategi maupun metodenya.

Perumusan tujuan pembelajaran erat kaitannya dengan karakteristik mata kuliah yang akan dibelajarkan. Perumusan tujuan pembelajaran baik yang bersifat umum atau standar kompetensi maupun yang bersifat khusus atau kompetensi dasar harus menggambarkan kemampuan yang akan dimiliki oleh mahasiswa setelah pembelajaran selesai. Standar kompetensi biasanya digambarkan dengan menggunakan kata-kata yang sangat umum, sedangkan kompetensi dasar biasanya digambarkan dengan kata kerja operasional yang dapat diukur.

\section{PENGEMBANGAN BAHAN PEMBELAJARAN}

Bahan pembelajaran merupakan informasi, alat, dan teks yang diperlukan dosen, guru, instruktur, tutor untuk perencanaan dan implementasi pembelajaran. Bahan ajar meliputi segala bentuk bahan yang digunakan untuk membantu dosen atau instruktur dalam melaksanakan kegiatan belajar mengajar di kelas. Bahan yang dimaksud bisa berupa bahan tertulis maupun bahan yang tidak tertulis. Bahan pembelajaran juga bisa diartikan sebagai seperangkat materi yang disusun secara sistematis, baik tertulis maupun tidak tertulis, sehingga tercipta lingkungan/suasana yang dapat memungkinkan mahasiswa untuk belajar. ${ }^{7}$

Bahan pembelajaran dapat diidentifikasi dalam beberapa bentuk: (1) bahan cetak seperti hand out, buku, modul, lembar kerja mahasiswa, brosur, leaflet, dan wallchart; (2) audio visual seperti video, film, dan VCD; (3) audio seperti radio, kaset, dan CD, (4) visual seperti foto, gambar, dan model/ maket, (5) multi media seperti CD interaktif, computer based, dan internet.

Dalam pengembangan bahan pembelajaran harus mencakup beberapa aspek seperti: judul bahan pembelajaran, mata pelajaran, standar kompetensi, kompetensi dasar, dan indikator. Bahan pembelajaran yang dikembangkan harus memuat petunjuk penggunaan bahan atau petunjuk belajar bagi mahasiswa dan dosen, mencantumkan rumusan tujuan yang ingin dicapai, informasi pendukung, latihan-latihan, petunjuk kerja, dan penilaian.

Alur Analisis pengembangan bahan ajar dapat dilakukan dengan terlebih dahulu merumuskan standar kompetensi, kemudian kompetensi dasar apa yang ingin dicapai, indiktor yang digunakan untuk melihat 
ketercapaian kompetensi, materi pelajaran, kegiatan pembelajaran, kemudian mengembangkan bahan ajarnya.

Ada perbedaan yang sangat mendasar antara bahan pembelajaran dan buku teks. Bahan pembelajaran merupakan bahan atau materi pembelajatan yang disusun secara sistematis yang digunakan dosen dan mahasiswa dalam kegiatan pembelajaran. Sedangkan buku teks merupakan sumber informasi yang disusun dengan struktur dan urutan berdasarkan bidang ilmu tertentu. ${ }^{8}$

Ciri bahan pembelajaran adalah menimbulkan minat baca, ditulis dan dirancang untuk mahasiswa, menjelaskan tujuan instruksional, disusun berdasarkan pola belajar yang fleksibel, struktur berdasarkan kebutuhan mahasiswa dan kompetensi yang akan dicapai, memberi kesempatan kepada mahasiswa untuk berlatih, mengakomodasi kesulitan mahasiswa, memberikan rangkuman, gaya penulisan komunikatif dan semi formal, kepadatan berdasarkan kebutuhan mahasiswa, dikemas untuk proses pembelajaran, mempunyai mekanisme untuk mengumpulkan umpan balik dari mahasiswa, menjelaskan cara mempelajari bahan ajar. Sedangkan buku teks memiliki ciri seperti mengasumsikan minat dari pembaca, ditulis untuk pembaca, dirancang untuk dipasarkan secara luas, belum tentu menjelaskan tujuan instruksional, disusun secara linear, struktur berdasar logika bidang ilmu, belum tentu memberikan latihan, tidak mengantisipasi kesulitan belajar mahasiswa, belum tentu memberikan rangkuman, gaya penulisan naratif, ilmiah, dan kadang tidak komunikatif, sangat padat, tidak memiliki mekanisme untuk mengumpulkan umpan balik dari pembaca. ${ }^{9}$

\section{STRATEGI PEMBELAJARAN}

Dalam mendesain pembelajaran, maka unsur yang sangat penting adalah bagaiman mendesain strategi dan metode pembelajaran yang tepat sehingga meteri atau bahan ajar dapat disampaikan secara lebih efektif dan efisien, serta memungkinkan untuk mencapai tujuan pendidikan secara tepat sasaran. Di dalam pendidikan Islam sangat banyak metode pendidikan Islam yang telah dikemukakan oleh para ahli, seperti Abd Rahman An-Nahlawi mengemukakan beberapa metode yaitu:

1. Metode hiwar (percakapan) Qur'ani dan Nabawi

2. Mendidik dengan kisah Qur'ani dan Nabawi

3. Mendidik dengan amtsal Qur'ani dan Nabawi

4. Mendidik dengan memberi teladan 
5. Mendidik dengan pembiasaan diri dan pengalaman

6. Mendidik dengan membuat senang (targhib) dan membuat takut (tarhib). ${ }^{10}$

Di dalam al-Qur'an juga sudah dikemukakan metode-metode dalam pendidikan Islam sebagaimana Q.S. al-Nahl (16): 125, yang berbunyi:

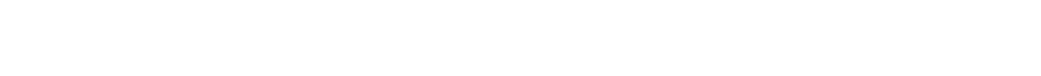

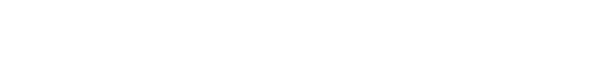

Serulah (manusia) kepada jalan Tuhanmu dengan hikmah dan pelajaran yang baik dan bantahlah mereka dengan cara yang baik. Sesungguhnya Tuhanmu Dialah yang lebih mengetahui tentang siapa yang tersesat dari jalan-Nya dan Dialah yang lebih mengetahui orang-orang yang mendapat petunjuk.

Sesungguhnya sangat banyak strategi dan metode yang dapat digunakan dalam pendidikan Islam yang semuanya tidak dapat disebutkan di sini. Aspek penting yang harus diperhatikan dalam mendesain strategi dan metode pembelajaran adalah prinsip-prinsip penggunaan metode pembelajaran itu sendiri. Ada tiga prinsip yang harus diperhatikan dalam memilih dan menggunakan metode pembelajaran, yakni: metode yang digunakan dapat mempermudah dosen dan mahasiswa dalam proses pembelajaran, metode yang digunakan berkesinambungan, dan metode yang digunakan fleksibel dan dinamis. ${ }^{11}$

\section{MEDIA PEMBELAJARAN}

Media secara bahasa mengandung makna perantara atau pengantar, atau pengantar pesan dari pengirim kepada penerima pesan. ${ }^{12}$ Media pembelajaran secara umum adalah manusia, benda ataupun peristiwa yang membuat kondisi mahasiswa dimungkinkan memperoleh pengetahuan, keterampilan, dan sikap..$^{13}$ Sedangkan media pembelajaran secara khusus adalah alat-alat grafis, fotografis, atau elektronis untuk menangkap, memproses, dan menyusun kembali informasi visual atau verbal. ${ }^{14}$

Dalam pendidikan Islam media pembelajaran dapat digolongkan sebagai berikut:

1. Media tulis atau cetak seperti al-Qur'an, hadis, tauhid, fikih dan sebagainya;

2. Benda-benda alam seperti manusia, hewan, tumbuh-tumbuhan, zat padat, zat cair, zat gas dan sbagainya;

3. Gambar-gambar, lukisan, diagram, peta dan grafik. Alat ini dapat dibuat dalam ukuran besar dan dapat pula dipakai dalam buku-buku teks atau bahan-bahan lain. 
4. Gambar yang dapat diproyeksi, baik dengan alat atau tanpa suara seperti foto, slide, film strip, televisi, video, dan sebagainya;

5. Audio recording (alat untuk didengar) seperti kaset, radio, piringan hitam, dan lain-lain yang semuanya diwarnai dengan ajaran agama. ${ }^{15}$

Dari pandangan di atas dapat dikemukakan bahwa media pembelajaran dalam pendidikan Islam adalah segala sesuatu yang dapat mengantarkan materi pembelajaran, atau dapat menciptakan suatu kondisi yang memudahkan bagi mahasiswa untuk mempelajari seluruh aspek dalam ajaran Islam. Yang terpenting adalah bahwa dalam penggunaan media itu selalu mencerminkan nilai-nilai ajaran Islam.

Di dalam pendidikan Islam keberadaan media pembelajaran sangat diperlukan, karena memberikan banyak manfaat, seperti: (1) membuat konkret konsep yang abstrak; (2) membawa obyek yang sukar didapat ke dalam lingkungan belajar mahasiswa; (3) dapat menampilkan obyek yang terlalu besar; (4) dapat menampilkan obyek yang tak dapat diamati dengan mata telanjang; (5) dapat mengamati gerakan yang terlalu cepat; (6) memungkinkan keseragaman pengamatan dan persepsi bagi pengalaman belajar mahasiswa; (7) membangkitkan motivasi belajar; dan (8) menyajikan informasi belajar secara konsisten dan dapat diulang maupun disimpan menurut kebutuhan. ${ }^{16}$

Abu Bakar Muhammad juga mengemukakan bahwa kegunaan media pembelajaran adalah: (1) mampu mengatasi kesulitan-kesulitan dan memperjelas materi pelajaran yang sulit; (2) mampu mempermudah pemahaman, dan mejadikan pelajaran lebih hidup dan menarik; (3) merangsang anak untuk bekerja dan menggerakkan naluri kecintaan menelaah (belajar) dan menimbulkan kemauan keras untuk mempelajari sesuatu, (4) membantu pembentukan kebiasaan, melahirkan pendapat, memperhatikan dan memikirkan suatu pelajaran, serta (5) menimbulkan kekuatan perhatian (ingatan) mempertajam dan melatih indera, perasaan, dan cepat belajar. ${ }^{17}$

Sangat tergambar dengan jelas bahwa kehadiran media pembelajaran dalam proses belajar-mengajar sangat penting artinya untuk membantu dosen dan mahasiswa. Dosen terbantu karena ia dengan mudah dapat memberikan pemahaman dan contoh-contoh serta uraian-uraian melalui media pembelajaran yang sesuai dengan materi yang akan disajikan. Mahasiswa terbantu karena ia dengan mudah dapat memahami materi pelajaran yang dipelajarinya berkat dukungan media yang menarik dan menumbuhkan minatnya untuk belajar.

Dengan demikian apabila dalam lembaga pendidikan Islam dapat memanfaatkan dan mengembangkan media sebaik mungkin di dalam 
proses pembelajarannya, maka dapat diduga mahasiswa akan memiliki pemahaman yang lebih baik tentang materi yang telah dipelajarinya. Dengan bantuan media, mahasiswa juga dapat memperbaiki akhlak dan perilakunya karena memperoleh pemahaman dari materi yang dipelajarinya serta contoh-contoh yang ditayangkan lewat media pembelajaran. Dengan bantuan media, tujuan pendidikan Islam yang telah ditetapkan akan dapat dicapai secara lebih efektif dan efisien.

\section{Evaluasi Pembelajaran}

Evaluasi pembelajaran merupakan suatu kegiatan yang tidak dapat dilepaspisahkan dari keseluruhan kegiatan proses belajar mengajar. Sebab, kegiatan evaluasi dimaksudkan untuk mengetahui sejauhmana tujuan pendidikan yang telah ditetapkan dapat tercapai.

Kegiatan evaluasi dalam pendidikan Islam tidak berbeda dengan kegiatan evaluasi dalam pendidikan secara umum, yang membedakan adalah aspek-aspek yang akan dievaluasi. Aspek-aspek yang harus menjadi sasaran evaluasi dalam pendidikan Islam adalah perkembangan mahasiswa atau peserta didik menurut ukuran ajaran Islam, seperti aspek: (1) ibadah; (2) perkembangan pemahaman tentang pelaksanaan menjadi khalifah Allah di muka bumi; (3) perkembangan keimanan dan ketakwaan; dan (4) perkembangan pemenuhan kewajiban hidup, berupa kewajiban yang bersifat duniawi dan ukhrawi. ${ }^{18}$

Secara umum ada tiga aspek yang dinilai dalam pendidikan Islam yakni aspek kognitif, aspek afektif dan aspek psikomotorik. Aspek kognitif berkaitan dengan bagaimana pemahaman mahasiswa terhadap materi pendidikan agama Islam yang telah dipelajarinya. Aspek afektif berkaitan dengan bagaimana sikap mahasiswa dan pandangan mahasiswa terhadap materi yang telah dipelajarinya. Aspek psikomotorik berkaitan dengan perilaku beragama mahasiswa setelah mempelajari ajaran Islam.

Di dalam pendidikan Islam, jenis penilaian yang digunakan sama dengan dengan jenis-jenis penilaian pembelajaran pada umumnya. Seperti penilaian formatif untuk mengetahui hasil belajar yang dicapai oleh mahasiswa setelah menyelesaikan program dalam satuan mata kuliah pada suatu mata pelajaran tertentu. Sedanghkan penilaian sumatif adalah evaluasi yang dilakukan terhadap hasil belajar peserta didik setelah mengikuti pelajaran dalam satu catur wulan, semester, atau akhir tahun. Penilaian diagnostik adalah untuk menganalisis kemajuan-kemajuan dan kesulitan-kesulitan belajar yang dialami oleh peserta didik/mahasiswa, atau untuk menganlisis hambatan-hambatan yang dialami oleh peserta didik dalam mempelajari suatu mata kuliah. ${ }^{19}$ 
Selain itu dapat pula digunakan penilaian unjuk kerja, hal ini sangat banyak berkaitan dengan aspek psikomorotik. Penilaian unjuk kerja adalah penilaian tindakan atau tes praktek yang secara efektif dapat digunakan untuk mengumpulkan berbagai informasi tentang bentuk-bentuk perilaku atau keterampilan yang diharapkan muncul dalam diri peserta didik setalah mengikuti pembelajaran. Bentuk tes unjuk kerja bisa melalui peraktek langsung, penilaian kinerja. ${ }^{20}$

Perubahan perilaku siswa sebagai perolehan dari hasil belajar dapat pula dinilai melalui portofolio. Portofolio adalah suatu penilaian yang dilakukan secara berkelanjutan untuk menilai perkembangan mahasiswa baik dari segi aspek kognitif, afektif maupun psikomotoriknya, dalam mata kuliah tententu dan dalam kurun waktu tertentu, yang dapat diamati dan diukur melalui kumpulan karya, atau dokumentasi yang dilakukan oleh dosen selama mahasiswa mengikuti pembelajaran/perkuliahan. Portofolio adalah satu cara yang efektif untuk melihat kemampuan mahasiswa ${ }^{21}$ selain melalui mid semester atau ujian akhir semester.

Dengan begitu, evaluasi pembelajaran dimaksudkan untuk mengukur dan mengevaluasi pencapaian tujuan pendidikan, yang diperoleh melalui proses pembelajaran. Proses evaluasi dapat saja dilakukan ketika proses pembelajaran berlangsung atau setelah sesi tahapan pembelajaran berlangsung. Inti dari evaluasi adalah untuk mengukur berapa banyak informasi yang diperoleh mahasiswa dalam proses pembelajaran, atau berapa banyak kompetensi yang dikuasai oleh mahasiswa, dan juga untuk mengukur perilaku-perilaku apa yang berubah dari mahasiswa setelah melalui proses pembelajaran.

\section{Profesionalitas Dosen}

Menurut Undang-Undang Nomor: 14 Tahun 2005 tentang Guru dan Dosen, bab 5 pasal 45 dinyatakan:

Dosen wajib memiliki kualifikasi akademik, kompetensi, sertifikat pendidik, sehat jasmani dan rohani, dan memenuhi kualifikasi lain yang dipersyaratkan satuan pendidikan tinggi tempat bertugas, serta memiliki kemampuan untuk mewujudkan tujuan pendidikan nasional. ${ }^{22}$

Pasal di atas mensyaratkan bahwa seorang dosen harus memiliki sejumlah kualifikasi dan kemampuan yang dapat mendukung tugas yang diembannya. Dosen tidak saja dipersyaratkan untuk memiliki kualifikasi akademik minimal magister sebagai simbol atas penguasaan dan kepakaran pada suatu bidang ilmu, tetapi juga harus memiliki sejumlah kemampuan untuk mentransfer ilmu pengetahuan yang dimilikinya kepada mahasiswa yang diajarnya. Seorang dosen juga wajib memiliki 
sertifikat untuk mendidik dan mengajar sebagai simbol dan pengakuan bahwa dosen yang bersangkutan memiliki kemampuan dan kewenangan untuk melakukan tugas-tugas kependidikan.

Dalam melaksanakan tugas keprofesionalan dosen berkewajiban:

1. Melaksanakan pendidikan, penelitian, dan pengabdian kepada masyarakat;

2. Merencanakan, melaksanakan proses pembelajaran, serta menilai dan mengevaluasi hasil pembelajaran;

3. Meningkatkan dan mengembangkan kualifikasi akademik dan kompetensi secara berkelanjutan sejalan dengan perkembangan ilmu pengetahuan, teknologi, dan seni;

4. Bertindak obyektif dan tidak diskriminatif atas dasar pertimbangan jenis kelamin, agama, suku, ras, kondisi fisik tertentu, atau latar belakang sosio-ekonomi peserta didik dalam pembelajaran;

5. Menjunjung tinggi peraturan perundang-undangan, hukum, dan kode etik, serta nilai-nilai agama dan etika; dan

6. Memelihara dan memupuk persatuan dan kesatuan bangsa. ${ }^{23}$

Dosen profesional harus memiliki kompetensi. Kompetensi tersebut meliputi kompetensi pedagogik, kompetensi kepribadian, kompetensi sosial, dan kompetensi profesional. ${ }^{24}$ Kompetensi pedagogik adalah kemampuan mengelola pembelajaran peserta didik, kompetensi kepribadian adalah kemampuan kepribadian yang mantap berakhlak mulia, arif, dan berwibawa serta menjadi teladan peserta didik, kompetensi profesional adalah kemampuan penguasaan materi pembelajaran secara luas dan mendalam, kompetensi sosial adalah kemampuan guru/dosen untuk berkomunikasi dan berinteraksi secara efektif dan efisien dengan peserta didik, sesama guru/dosen, orangtua peserta didik, dan masyarakat. ${ }^{25}$

Sangat jelas tergambar bahwa dosen profesional adalah dosen yang tidak hanya memiliki kemampuan dan kepakaran terhadap suatu bidang ilmu, tetapi juga harus memiliki kemampuan untuk merencanakan dan melaksanakan serta mengevaluasi pembelajaran dengan baik. Seorang dosen harus mampu merencanakan pembelajaran sebaik mungkin yang berangkat dari tujuan pembelajaran yang ingin dicapai serta kebutuhan belajar peserta didik. Perencanaan pembelajaran yang baik akan mampu menganalisis segala kondisi dan kemampuan umum mahasiswa yang akan belajar, menganalisis lingkungan belajar mahasiswa, menganalisis dan mengembangkan bahan pembelajaran, menganlaisis strategi dan metode pembelajaran yang akan digunakan, serta mampu menggunakan mediamedia pembelajaran, baik media pembelajaran yang sederhana maupun media pembelajaran yang berbasis teknologi. 
Dosen dan guru yang profesional memiliki kemampuan untuk merancang dan merencanakan program pembelajaran; mengembangkan program pembelajaran; mengelola pelaksanaan program pembelajaran; menilai proses dan hasil pembelajaran serta mendiagnosis faktor yang mempengaruhi keberhasilan proses pembelajaran. ${ }^{26}$ Dari sisi inilah kemudian kebijakan pemerintah yang memberikan penghargaan kepada para guru besar atau profesor yang tidak lagi melalui proses sertifikasi banyak menuai kritikan. Alasan dari kelompok ini bahwa sekalipun para guru besar itu memiliki kepakaran dalam bidang ilmu tertentu, tetapi boleh jadi banyak di antara mereka yang tidak memiliki keterampilan dan kemampuan yang memadai untuk mendesain pembelajaran dengan baik, melaksanakan pembelajaran sesuai dengan kompetensi yang ingin dicapai dalam mata kuliah yang diajarkannya, dan memberikan evaluasi sesuai dengan kompetensi yang diharapkan.

Kemampuan untuk mendesain pembelajaran dapat dijadikan titik awal untuk upaya perbaikan kualitas pendidikan, karena dalam desain pembelajaran tahapan yang akan dilakukan oleh dosen telah dirancang dengan baik mulai dari menganalisis tujuan pembelajaran, sampai pada mengevaluasi hasil pembelajaran. Desain pembelajaran yang dilakukan oleh dosen memungkinkan dosen itu sendiri untuk mengintegrasikan semua variabel yang mempengaruhi belajar, seperti variabel kondisi pembelajaran, variabel strategi dan metode pembelajaran serta hasil pembelajaran. ${ }^{27}$

Pembelajaran yang didesain dengan baik oleh dosen akan memberi peluang yang lebih besar kepada mahasiswa untuk terlibat aktif dalam proses pembelajaran, sehingga mahasiswa dapat menemukan sendiri makna atau mahasiswa mampu mengkonstruksi sendiri pengetahuan yang telah dipelajarinya. Hal ini dapat terwujud karena dosen profesional sebelum memasuki kelas telah merancang berbagai strategi pembelajaran yang dapat ditempuh untuk melibatkan mahasiswa secara aktif dalam belajar. Strategi pembelajaran aktif yang dikembangkan akan menghindarkan dosen dan mahasiswa dari pembelajaran yang hanya mendorong peserta didik/mahasiwa untuk belajar dengan sistem hafalan (memorizing) dan berorientasi pada ijazah (certificate oriented). Peserta didik mencari ilmu hanya sebuah proses untuk mendapatkan ijazah, sedangkan semangat dan kualitas keilmuan menempati prioritas berikutnya. ${ }^{28}$

Model pembelajaran memorizing dan certificate oriented diistilahkan oleh Paulo Freire dengan pendidikan bergaya bank ((banking education). Dalam pendidikan gaya bank, yang dibutuhkan peserta didik bukanlah pemahaman akan isi, tetapi sekedar hafalan (memorization), dan jika peserta 
didik sudah sukses menghafal berarti telah memenuhi kewajibanya. ${ }^{29}$ Pembelajaran model ini juga disebut pembelajaran gaya komando. ${ }^{30}$ Pendidikan gaya bank maupun pendidikan gaya komando, menempatkan guru/dosen pada posisi yang sangat menentukan perencanaan dan proses pembelajaran. Guru/dosen mengajar, dan siswa belajar, dan bukanya antara guru dan peserta didik saling membelajarkan, guru adalah subyek proses belajar, dan peserta didik adalah obyeknya, dan bukannya guru serta peserta didik merupakan subyek belajar dan realita adalah obyek belajar. Semua perencanaan ditentukan oleh guru, disampaikan kepada peserta didik, dan mereka menerima pelajaran. Pembelajaran seperti ini menghambat dan bahkan mematikan kreativitas dan pengembangan potensi peserta didik. ${ }^{31}$

Jelaslah bahwa desain pembelajaran merupakan salah satu unsur yang sangat menentukan tingkat profesionalitas dosen. Kemampuan untuk mendesain pembelajaran dengan baik merupakan bagian tidak terpisahkan dari kompetensi paedagogik yang harus dimiliki oleh seorang dosen. Dosen profesional adalah yang memiliki kepakaran terhadap suatu bidang ilmu yang dikajinya, dan sekaligus memiliki kemampuan untuk merancang suatu model pembelajaran yang dapat mentransformasikan ilmu yang dimilikinya, serta dapat mengukur sajuahmana keberhasilan transformasi ilmu yang telah dilakukannya.

\section{PENUTUP}

Desain pembelajaran atau proses merancang pembelajaran merupakan suatu rangkaian proses dari keseluruhan proses pembelajaran. Desain pembelajaran meliputi penetapan tujuan pembelajaran yang disesuaikan dengan karakteristik mata kuliah dan kebutuhan belajar peserta didik/ mahasiswa; pengembangan materi pembelajaran baik dalam bentuk buku ajar, modul maupun hand out yang dapat memancing minat dan gairah siswa untuk belajar; penetapan strategi dan metode pembelajaran yang memungkinkan dan memberi peluang lebih besar kepada mahasiswa untuk belajar secara aktif; perancangan media pembelajaran yang sesuai dengan tujuan pembelajaran; serta pengevaluasian proses dan hasil belajar.

Kemampuan untuk mendesain pembelajaran berdasarkan landasan ilmiah merupakan bagian dari profesionalitas dosen. Dosen profesional tidak hanya wajib memiliki kemampuan dan kepakaran, tetapi juga harus memiliki kemampuan untuk merancang suatu proses alih pengetahuan dari sang pakar ke mahasiswanya melalui kegiatan pembelajaran. Desain pembelajaran yang baik akan menghindarkan dosen dan mahasiswa dari kegiatan pembelajaran yang monoton dan membosankan. Oleh karena itu, sudah saatnya setiap dosen sebelum masuk kelas harus mendesain pembelajaran dengan baik sebagai bagian dari tugas profesionalnya. 


\section{CATATAN AKHIR:}

1. Dede Rosyada, Paradigma Pendidikan Demokratis: Sebuah Model Pelibatan Masyarakat dalam Penyelenggaraan Pendidikan. Jakarta: Prenada Media, 2004, h. 91.

2. Kenneth D. Moore, Clasroom Teaching Skill, New York: McGraw Hill, 2001, h. 5.

3. Hisyam Zaini, dkk., Desain Pembelajaran di Perdosenan Tinggi, Yogyakarta: Center for Teaching Staff Development (CTSDP), 2002, h. 18.

4. Desain Pembelajaran, http://blog.persimpngan.com/blog/2007/08/14/desainpembelajaran, diakses tanggal 1 Desember 2007.

5. Desain Pembelajaran, http://blog.persimpngan.com/blog/2007/08/14/desainpembelajaran, diakses tanggal 1 Desember 2007.

6. Workshop Desain Pembelajaran, http://rbi-online.org/7p=45, diakses tanggal 2 Desember 2007.

7. Pengembangan Bahan Ajar, http://akhmad sudrajat.wordpress.com./ diakses tanggal 22 Nopember 2007.

8. Pengembangan Bahan Ajar, http://akhmad sudrajat.wordpress.com./

9. Pengembangan Bahan Ajar, http://akhmad sudrajat.wordpress.com./

10. Abd. Rahman An-Nahlawi, Ushul al-Tarbiyat al-Islamiyah wa Asalibuha, diterjemahkan oleh Herry Nur Ali, Prinsip-prinsip dan Metoda Pendidikan Islam dalam Keluarga, di Sekolah, dan di Masyarak. Bandung: CV. Dipoengoro, 1992, h., 304.

11. Ramayulis, Ilmu Pendidikan Islam, cet. IV, Jakarta: Kalam Mulia, 2004, h. 164.

12. Azhar Arsyad, Media Pembelajaran, Jakarta: PT. RajaGrafindo, 2004, h. 3.

13. Vernon S. Gerlach dan Donald P. Ely dalam Zakiah Daradjat, dkk., Ilmu Pendidikan Islam, Jakarta: Bumi Aksara, 1996, h. 80.

14. Azhar Arsyad, Media Pembelajaran, h. 3.

15. Zakiah Daradjat dkk., Ilmu Pendidikan Islam, h. 81.

16. Yusuf Hadi Harso dalam Amir Daien Indrakusumah, Pengantar Ilmu Pendidikan. Surabaya: Usaha Nasional, 1973, h. 146.

17. Abu Bakar Muhammad, Pedoman Pendidikan dan Pengajaran, Surabaya: Usaha Nasional, 1981, h. 97.

18. Ramayulis, Ilmu Pendidikan Islam, h. 202.

19. Ramayulis, Ilmu Pendidikan Islam, h. 202.

20. Kunandar, Guru Profesional: Implementasi Kurikulum Tingkat Satuan Pendidikan dan Persiapan menghadapi Sertifikasi Guru. Jakarta: PT RajaGrafindo Persada, h. 374.

21. Sumarna Suraprata dan Muhammad Hatta, Penilaian Portofolio: Implementasi Kurikulum 2004, Bandung: PT. Remaja Rosdakarya, 2004, h. 30.

22. Undang-Undang Nomor: 14 Tahun 2005, tentang Guru dan Dosen, Jakarta: Sinar Grafika, 2006, h. 22.

23. Undang-Undang Nomor: 14 Tahun 2005, tentang Guru dan Dosen, h. 22.

24. Undang-Undang Nomor: 14 Tahun 2005, tentang Guru dan Dosen, h. 22.

25. Undang-Undang Nomor: 14 Tahun 2005, tentang Guru dan Dosen, h. 22.

26. Kunandar, Guru Profesional: Implementasi Kurikulum Tingkat Satuan Pendidikan dan Persiapan menghadapi Sertifikasi Guru, h. 57. 
27. Wahyuddin Nur Nasution, Desain Pembelajaran, http://www.harian-global. com/news.30264.23, Saturday 01 December 2007, diakses tanggal 12 Desember 2007.

28. Ismail SM, Nurul Huda, dan Abd. Kholiq (Ed.), Paradigma Pendidikan Islam. Yogyakarta: Pustaka Pelajar, 2001, h. 284-285.

29. Paulo Freire, The Politic of Education: Culture, Power, and Liberation, diterjemahkan oleh Agung Prihantoro dan Fuad Arif Fudiyanto, Politik Pendidikan: Kebudayaan, Kekuasaan, dan Pembebasan, Yogyakarta: Pustaka Pelajar, 1999, h. 28.

30. Muska Mosston, Teaching from Command to Discovery, California: Wadsworth Publishing Company, 1972, h. 35.

31. John L. Elias, Paedagogue of Liberation, Florida: Kreigar Publishing Company, 1994, h. 113.

\section{DAFTAR PUSTAKA:}

Azhar Arsyad, Media Pembelajaran, Jakarta: PT. RajaGrafindo, 2004.

Desain Pembelajaran, http://blog.persimpngan.com/blog/2007/08/14/desainpembelajaran, diakses tanggal 1 Desember 2007.

Gerlach, Vernon S. dan Donald P. Ely dalam Zakiah Daradjat, dkk., Ilmu Pendidikan Islam, Jakarta: Bumi Aksara, 1996.

Harso, Yusuf Hadi dalam Amir Daien Indrakusumah, Pengantar Ilmu Pendidikan. Surabaya: Usaha Nasional, 1973.

Ismail SM, Nurul Huda, dan Abd. Kholiq (Ed.), Paradigma Pendidikan Islam. Yogyakarta: Pustaka Pelajar, 2001.

Kunandar, Guru Profesional: Implementasi Kurikulum Tingkat Satuan Pendidikan dan Persiapan menghadapi Sertifikasi Guru. Jakarta: PT RajaGrafindo Persada.

Moore, Kenneth D., Clasroom Teaching Skill, New York: McGraw Hill, 2001.

Muhammad, Abu Bakar, Pedoman Pendidikan dan Pengajaran, Surabaya: Usaha Nasional, 1981.

An-Nahlawi, Abd. Rahman, Ushul al-Tarbiyat al-Islamiyah wa Asalibuha, diterjemahkan oleh Herry Nur Ali, Prinsip-prinsip dan Metoda Pendidikan Islam dalam Keluarga, di Sekolah, dan di Masyarak. Bandung: CV. Dipoengoro, 1992.

Nasution, Wahyuddin Nur, Desain Pembelajaran, http://www.harian-global.com/ news.30264.23, Saturday 01 December 2007, diakses tanggal 12 Desember 2007.

Pengembangan Bahan Ajar, http://akhmadsudrajat.wordpress.com./ diakses tanggal 22 Nopember 2007.

Ramayulis, Ilmu Pendidikan Islam, cet. IV, Jakarta: Kalam Mulia, 2004.

Rosyada, Dede, Paradigma Pendidikan Demokratis: Sebuah Model Pelibatan Masyarakat dalam Penyelenggaraan Pendidikan. Jakarta: Prenada Media, 2004.

Suraprata, Sumarna dan Muhammad Hatta, Penilaian Portofolio: Implementasi Kurikulum 2004, Bandung: PT. Remaja Rosdakarya, 2004.

Undang-Undang Nomor: 14 Tahun 2005, tentang Guru dan Dosen, Jakarta: Sinar Grafika, 2006.

Workshop Desain Pembelajaran, http://rbi-online.org/7p=45, diakses tanggal 2 Desember 2007. 
Zaini, Hisyam, dkk., Desain Pembelajaran di Perdosenan Tinggi, Yogyakarta: Center for Teaching Staff Development (CTSDP), 2002.

Freire, Paulo, The Politic of Education: Culture, Power, and Liberation, diterjemah-kan oleh Agung Prihantoro dan Fuad Arif Fudiyanto, Politik Pendidikan: Kebudayaan, Kekuasaan, dan Pembebasan, Yogyakarta: Pustaka Pelajar, 1999.

Mosston, Muska, Teaching from Command to Discovery, California: Wadsworth Publishing Company, 1972.

Elias, John L., Paedagogue of Liberation, Florida: Kreigar Publishing Company, 1994. 